\title{
ONE-YEAR CLINICAL EVALUATION OF TOOTH-COLORED MATERIALS IN NON- CARIOUS CERVICAL LESIONS
}

\author{
AVALIAÇÃO CLÍNICA DE RESTAURAÇÕES DE \\ LESÕES CERVICAIS NÃO CARIOSAS
}

\author{
Sérgio Lima SANTIAGO \\ Adjunct Professor of Dentistry at Federal University of Ceará. \\ Eduardo Batista FRANCO \\ Professor, Department of Operative Dentistry, Endodontics and Dental Materials, Bauru School of Dentistry- University of São Paulo. \\ Juliano Sartori MENDONÇA \\ Graduate Student attending the Ph.D. program in Operative Dentistry of Bauru School of Dentistry - University of São Paulo. \\ José Roberto Pereira LAURIS \\ Assistant Professor of Department of Pedodontics, Orthodontics and Public Health, Bauru School of Dentistry- University of São Paulo. \\ Maria Fidela de Lima NAVARRO \\ Professor and Dean of Bauru School of Dentistry- University of São Paulo.
}

\begin{abstract}
7 he purpose of this study was to assess the clinical performance of bonded composite (Excite/Tetric Ceram -
Vivadent) versus a resin-modified glass ionomer cement (Vitremer - 3M) for restoring non-carious cervical lesions. A total of 70 restorations (thirty-five per material) were placed in 30 patients, 18-50 aged, by one operator. Rubber dam was employed in all cases, lesions were pumiced, enamel margins were not beveled, and no mechanical retention was placed. The restorations were directly assessed by two independent evaluators using modified-USPHS criteria for six clinical categories. The ratings for clinical acceptability restorations (alfa plus bravo) were as follows (Tetric Ceram/Vitremer): retention (86\%/100\%), marginal integrity (100\%/100\%), marginal discoloration (100\%/ $100 \%)$, wear $(97 \% / 100 \%)$, postoperative sensitivity $(100 \% / 100 \%)$ and recurrent caries $(100 \% / 100 \%)$. Statistical analysis was completed with Fisher's exact or Pearson Chi-square tests at a significance level of 5\% $(\mathrm{P}<0.05)$. Results showed that almost all restorations were clinically satisfactory with no significant differences between materials groups. Five restorations of Excite/Tetric Ceram failed. No restorations of Vitremer have yet failed.
\end{abstract}

UNITERMS: Cervical lesion; Composite resins; Glass ionomer cements.

\section{INTRODUCTION}

The development of the acid-etching technique of the enamel and of the dentine resulted in restorations with a notable increase in durability and longevity, once the adhesion of the resin composite to the dental tissues reduces or eliminates the need to remove healthy dental structure. The dental profession has tried many materials and techniques in an attempt to obtain the best performance possible for its patients that reflects the difficulty of this challenge ${ }^{3}$.

New adhesive systems are being continually developed with the purpose of increasing the adhesion of resin composite to the dental structure, favoring its retention and reducing marginal microleakage. At the same time, these systems provided the simplification of clinical procedures in the execution of adhesive aesthetic restorations. One bottle adhesives entered the market as an option to the conventional three-step systems. They contain priming substances, like HEMA (2-hydroxyethyl methacrylate) or PENTA (dipentaerythritol penta-acrylate monophosphate), in the same bottle with low-viscosity resins. A solvent (ethanol or acetone) is also added to work as a water 
chaser and facilitates the exchange of water to monomers inside the collagen web ${ }^{5,7}$.

The restoration of non-carious cervical lesions (NCCL) presents some inconvenience, mainly concerning the location of their margins, because most of the time, the cervical margin is determined in cement and/or dentine. This characteristic makes the cervical margin more susceptible to microleakage, causing cavosurface stains, postoperative sensitivity and the incidence of carious lesions. Besides, the quality of the substratum in those types of lesions presents sclerotic and/or vitrified dentine in the great majority of the cases. According to Yoshiyama, et al. ${ }^{16}$ the adhesive quality of the sclerotic dentine is inferior to the one of the non-sclerotic dentine, as the pattern of acid conditioning is harmed by the morphology of this more mineralized dentine. So, the clinical evaluation of these types of lesions is more sensible than the others mainly in short periods.

Numerous studies have examined the retention rates after restoration of NCCL with resin composite and glass ionomer cement. In general, those teeth restored with glass ionomer cement (GIC) tended to show high retention rates ${ }^{4,12,13}$. According to $\mathrm{Neo}$, et al. ${ }^{12}$ the GIC, light-cured or the auto-cured, continue to be the most retentive material for non-carious cervical lesions which is widely supported by numerous clinical trials.

The aim of this study is to evaluate the clinical performance of an one-bottle adhesive system (Excite/ Tetric Ceram) in the restoration of non-carious cervical lesions, comparatively to a resin-modified glass ionomer cement (Vitremer) using a modified-USPHS categories and criteria for one year.

\section{MATERIALS AND METHODS}

\section{Selection of patient and teeth}

Thirty volunteer patients of both sexes, ranging in age from 18 to 50 years, were properly clarified about the study and, in agreement, signed a term of acceptance which had been reviewed and approved by an institutional review board. The criteria for inclusion of a patient in this study were: appropriate oral hygiene, low decay index, absence of periodontal disease, bruxism and traumatic occlusion, no wear facets, presence of at least two non-carious cervical lesions to be restored. All subjects presented a minimum of one pair of non-carious cervical lesions, with a depth equal or greater than $1 \mathrm{~mm}$, independently of their location in the dental arcade. Preferably, the selected teeth should be healthy or satisfactorily restored, without gingival inflammation or periapical alterations and in occlusion. One tooth in each pair received a restoration placed with the adhesive restorative system in study (Excite / Tetric Ceram Vivadent) while the other with the resin-modified glass ionomer cement (Vitremer - 3M). The order of the materials was on a random basis. The distribution of restorations was 70 percent in maxillary arch and 30 percent in mandibular arch, and the majority in premolar teeth $(80 \%)$. Ten percent were placed in molar and 10 percent in anterior teeth.

\section{Restorative procedures}

A total of 70 restorations (thirty five per material) were performed by one operator. Twenty six patients received two restorations each, 3 patients received four restorations each and one patient received six restorations. No cavity preparation was carried out. Enamel margins were not beveled, and no mechanical retention was placed. Rubber dam was employed in all cases and cavities were pumiced with a prophy cup.

\section{Restoration with Resin Composite}

Enamel and dentin were etched for 30 seconds with $37 \%$ phosphoric acid gel. The etchant was rinsed off with water spray. One coat of adhesive system (Excite - Vivadent) was applied to the visibly moist dentin surface and brushed gently for $10 \mathrm{~s}$. Following the evaporation of alcohol solvent, the self-priming adhesive was light-cured for $20 \mathrm{~s}$ according to the manufacturer's instructions. The resin composite (Tetric Ceram - Vivadent) was placed using a minimum of two increments of composite. Each increment was light cured for 40 seconds, by means of a visible light cure unit (XL 3000 - 3M), with minimum light intensity of $600 \mathrm{~mW} / \mathrm{cm}^{2}$ calibrated with a curing radiometer (Demetron Corp.) before each restoration. The restorations were immediate finished with the removal of eventual excesses with a scalp blade \#12, while the mediate finishing and polishing were performed after one week, starting with 12-fluted tungsten carbide burs (Jet Burs), the Enhance polishing system (Dentsply) and Sof-Lex polishing discs (3M).

\section{Restoration with Resin-modified Glass Ionomer Cement}

The resin-modified glass ionomer cement (Vitremer - 3M) was applied according to the manufacturer's instructions. The primer was applied 
with a brush (Microbrush) on the surface of the lesion, keeping in contact with it for a period of 30 seconds and light cured for 20 seconds. The glass ionomer cement was manipulated, in the powder/liquid ratio of $1: 1$, in a glass plate with a spatula \#24. After the manipulation, the material was inserted in the lesion with the aid of disposable tips and Centrix type syringe. The restoration was light cured for 40 seconds. The removal of the excess material was carried out with scalp blade \#12. The finishing and polishing were similarly carried out as resin composite.

The restorative treatments for both gruops were performed during one month.

\section{Clinical evaluation}

The operator was not involved in the evaluation of the restorations. Two examiners unaware of which material had been used did all evaluations, creating a blinded study. Modified US Public Health Service criteria (Table 1) was used to evaluate retention, marginal integrity, marginal discoloration, wear, postoperative sensitivity and secondary caries at both baseline and at 12 months. Photographs were taken, with standardized magnification of $1.5 \mathrm{X}$, using a
Nikon Medical camera with Ektachrome film for color slides at each time interval. The baseline was considered after one week, immediately after finishing and polishing procedures and were performed during one month. Clinical evaluations will be performed yearly.

Statistical analysis compared the ratings of each criterion between materials using the Pearson chisquare or Fisher's exact test at a level of significance of $5 \%(\mathrm{p}<0.05)$.

\section{RESULTS}

All patients were available for recall at 12 months. This equates to $100 \%$ recall rate and it is expected to continue high at others periods because Bauru Dental School has an agreement with the Bauru Military Police and great part of the patients are police officers. The date for recall was established as the mean of all procedure date in just one day. But four patients were not available and were examined during the next week. Data for retention, marginal integrity, marginal discoloration, wear, postoperative sensitivity and secondary caries were presented in Table 2 . No

TABLE 1- Modified-USPHS rating criteria

\begin{tabular}{|c|c|c|}
\hline CATEGORY & RATING & CRITERIA \\
\hline \multirow[t]{2}{*}{ Retention } & Alfa $(A)$ & Retained \\
\hline & Charlie (C) & Partially retained or missing \\
\hline \multirow[t]{3}{*}{ Marginal Integrity } & Alfa $(A)$ & Closely adapted, no visible crevice \\
\hline & Bravo (B) & Visible crevice, explorer will penetrate \\
\hline & Charlie $(\mathrm{C})$ & Crevice in which dentin is exposed \\
\hline \multirow[t]{3}{*}{ Marginal Discoloration } & Alfa $(A)$ & No discoloration \\
\hline & Bravo (B) & Superficial staining (without axial penetration) \\
\hline & Charlie $(\mathrm{C})$ & Deep staining (with axial penetration) \\
\hline \multirow[t]{3}{*}{ Wear } & Alfa $(A)$ & Continuous \\
\hline & Bravo (B) & Discontinuous, no dentin exposed \\
\hline & Charlie $(\mathrm{C})$ & Discontinuous, dentin exposed \\
\hline \multirow[t]{2}{*}{ Postoperative Sensitivity } & Alfa $(A)$ & None \\
\hline & Charlie $(\mathrm{C})$ & Present \\
\hline \multirow[t]{2}{*}{ Secondary Caries } & Alfa $(A)$ & No caries present \\
\hline & Charlie $(\mathrm{C})$ & Caries present \\
\hline
\end{tabular}


restorations exhibited postoperative sensitivity and caries at 12 months. There were no statistically significant differences between baseline and 1 year for all evaluated criteria.

Table 2 shows that five restorations of resin composite were lost after one year and no restoration of glass ionomer cement was lost. This equates to $100 \%$ retention for Vitremer and $86 \%$ retention for Tetric-Ceram restorations after 1 year. However, there was no statistically significant difference between materials, but is close to significance at 1 year. The failure occurred in five adults patients (aged 30, 32, 41,48 and 49 years) by the dislodgment of the restoration in premolar teeth.

In respect to marginal integrity, the Bravo-rating for Tetric Ceram at baseline was due to lack of material at the gingival margin. The change in ratings from Alfa to Bravo for both materials during the year was due to slight fracture along the cavity margins.

There were no obvious differences between the materials in marginal discoloration. Only one restoration was rating Bravo after 1 year for resin composite and two restorations were rating Bravo for glass ionomer cement at the same period.

In respect to wear, Tetric Ceram was worse than Vitremer. The composite restorations presented 24

TABLE 2- Evaluation of the materials at baseline and after one year

\begin{tabular}{llll}
\hline CATEGORY MATERIAL & BASELINE & ONE YEAR
\end{tabular}

\begin{tabular}{|c|c|c|c|c|c|c|c|c|c|}
\hline & & \multicolumn{4}{|c|}{ Scores* } & \multicolumn{4}{|c|}{ Scores* } \\
\hline & & A & B & C & $\% A+B$ & $\mathbf{A}$ & B & C & $\% A+B$ \\
\hline \multirow[t]{3}{*}{ Retention } & Excite/ TC & 35 & 0 & 0 & $100 \%$ & 30 & 0 & 5 & $86 \%$ \\
\hline & Vitremer & 35 & 0 & 0 & $100 \%$ & 33 & 2 & 0 & $100 \%$ \\
\hline & & \multicolumn{4}{|c|}{ Fisher; $p=1.000$} & \multicolumn{4}{|c|}{ Fisher; $p=0.053$} \\
\hline Marginal & Excite/ TC & 34 & 1 & 0 & $100 \%$ & 20 & 10 & 0 & $100 \%$ \\
\hline \multirow[t]{2}{*}{ Integrity } & Vitremer & 35 & 0 & 0 & $100 \%$ & 27 & 8 & 0 & $100 \%$ \\
\hline & & \multicolumn{4}{|c|}{ Fisher; $p=1.000$} & \multicolumn{4}{|c|}{ Fisher; $p=0.41$} \\
\hline Marginal & Excite/ TC & 35 & 0 & 0 & $100 \%$ & 29 & 1 & 0 & $100 \%$ \\
\hline \multirow[t]{2}{*}{ Discoloration } & Vitremer & 35 & 0 & 0 & $100 \%$ & 35 & 0 & 0 & $100 \%$ \\
\hline & & \multicolumn{4}{|c|}{ Fisher; $p=1.000$} & \multicolumn{4}{|c|}{ Fisher; $p=0.46$} \\
\hline \multirow[t]{3}{*}{ Wear } & Excite/ TC & 35 & 0 & 0 & $100 \%$ & 24 & 5 & 1 & $97 \%$ \\
\hline & Vitremer & 35 & 0 & 0 & $100 \%$ & 34 & 1 & 0 & $100 \%$ \\
\hline & & \multicolumn{4}{|c|}{ Fisher; $p=1.000$} & \multicolumn{4}{|c|}{$c^{2}=5.03 ; p=0.08$} \\
\hline Postoperative & Excite/ TC & 35 & 0 & 0 & $100 \%$ & 35 & 0 & 0 & $100 \%$ \\
\hline \multirow[t]{2}{*}{ Sensitivity } & Vitremer & 35 & 0 & 0 & $100 \%$ & 35 & 0 & 0 & $100 \%$ \\
\hline & & \multicolumn{4}{|c|}{ Fisher; $p=1.000$} & \multicolumn{4}{|c|}{ Fisher; $p=1.000$} \\
\hline Secondary & Excite/ TC & 35 & 0 & 0 & $100 \%$ & 35 & 0 & 0 & $100 \%$ \\
\hline \multirow[t]{2}{*}{ Caries } & Vitremer & 35 & 0 & 0 & $100 \%$ & 35 & 0 & 0 & $100 \%$ \\
\hline & & \multicolumn{4}{|c|}{ Fisher; $p=1.000$} & \multicolumn{4}{|c|}{ Fisher; $p=1.000$} \\
\hline
\end{tabular}

${ }^{*}$ Represents the number of restorations assigned to each specific score. Right column indicates the percent of restorations with scores $A$ and $B$ 
cases having Alfa rating and one case having Charlie rating at 1 year. The anatomic form of all restorations with Vitremer remained stable during the evaluated period. However there were no statistically significant difference between the materials, but is close to significance at 1 year.

\section{DISCUSSION}

The sample size of 30 patients, the number of restorations (35 per material) and the distribution of restorations (maximum of 3 pairs in the same patient) are in accordance to the American Dental Association guidelines when testing a new material ${ }^{1}$.

In the current study the retention rate for resinmodified glass ionomer cement was $100 \%$ and for resin composite was $86 \%$. Five restorations (14\%) of Excite/ Tetric Ceram were missing or dislodged and were judge to have failed. The high retention rate for Vitremer can be attributed to better mechanical properties and better bond to tooth tissue than the conventional ones ${ }^{14,15}$. The use of primers containing HEMA produces interfacial appearances very similar to those of dentin adhesive systems. According to Sidhu; Watson ${ }^{14}$, the term adsorption layer has been applied to this structure, and could be important in the maintenance of the fit of the restoration to compensate for the contraction of the resin on the polymerization.

Browning; Brackett; Gilpatrick ${ }^{3}$ in 24 months evaluation of resin-based materials showed a failure of $11 \%$ to $14 \%$. In a study evaluating an experimental formulation of the Gluma system used with resin composite showed that four restorations were lost after three years, resulting in 11-12\% of failure ${ }^{11}$. In a recent study, Neo, et al. ${ }^{12}$ showed a retention rate of $65 \%$ of resin-based material at 18 months evaluation. According to Burrow; Tyas ${ }^{4}$ a wide variation between materials and research groups demonstrates the lack of reliability of some of these materials.

Investigators have determined that factors other than the restorative materials may significantly influence the clinical performance of cervical restorations. The contributory factors leading to the failure of the bond are probably multifactorial which could include sclerosed dentin, location of lesion, lesion size and shape, operator variability, specific product batch and even occlusal factors ${ }^{2,6,8,9,10}$.

Frequently, the failure of these restorations has been linked to the stiffness of the restorative material. Yap, $\mathrm{NeO}^{14}$ affirmed that the elastic modulus appears to be a significant property in retention of restorations used in NCCL. When a more rigid composite material such as a hybrid is used the shear stress at the adhesive interface could exceed the compressive stress, thus acting primarily on the dentine bond ${ }^{15}$. The introduction of low modulus resin based materials has been promoted as possibly beneficial for restoring noncarious cervical lesions. However the results are unclear, bringing into question the role that material's stiffness plays in determining retention in a noncarious cervical lesion ${ }^{3,4}$.

In addition, the fact that all failures occured in premolars may be because the majority of the restorations were inserted in these teeth $(80 \%)$ and the probability of failure were higher than in molar $(10 \%)$ and anterior teeth $(10 \%)$.

In respect to marginal integrity, the large number of restorations of resin composite exhibiting a decline in rating (Alfa to Bravo) is probably due to no margins beveled and/or to the small fracture of the cavo-surface margin and material due to stress from polymerization shrinkage. Despite the improved bond strength of the materials, increased tooth flexure may still contribute to localized defects in marginal integrity for both materials.

All of resin-modified GIC restorations had a good anatomical form after 12 months. In the case of resin composite one restoration demonstrated a nonacceptable clinical condition. However, the poor wear resistance of resin composite could be explained by the location of this restoration in molar tooth that was more sensible to brushing procedures.

\section{CONCLUSION}

The results of this study revealed a better quality of resin-modified glass ionomer cement restorations, which showed no cases of non-acceptable restorations in any aspect. One restoration of resin composite were evaluated as non-acceptable in wear criterion. However, no statistically significant difference between the materials was found. The results of this study need to be substantiated for a longer period of evaluation.

\section{RESUMO}

Avaliou-se o desempenho clínico de um sistema restaurador adesivo (Excite - Tetric Ceram/ Vivadent) e do cimento de ionômero de vidro modificado por resina (Vitremer/ 3M) na restauração de lesões cervicais não cariosas por meio do sistema de avaliação 
do USPHS modificado. Um total de setenta restaurações, trinta e cinco por material, foi realizado por um único operador em trinta pacientes voluntários com idades de 18 a 50 anos. Previamente à execução das restaurações, foi realizada uma profilaxia com pedra-pomes e água a fim de remover quaisquer resíduos. As lesões cervicais não foram submetidas a qualquer tipo de preparo cavitário, sendo restauradas sob isolamento absoluto e de acordo com as instruções do fabricante. Todas as restaurações foram avaliadas pelo método direto por dois examinadores usando os critérios de retenção (R), integridade marginal (IM), descoloração marginal (DM), desgaste (D), sensibilidade pós-operatória $(S)$ e incidência de cárie (IC). Ao final de um ano, os resultados de restaurações clinicamente satisfatórios (escores Alfa e Bravo) obtidos para resina composta e cimento de ionômerto de vidro modificado por resina foram respectivamente: R (86\%/100\%), IM (100\%/100\%), DM (100\%/100\%), D (97\%/100\%), S (100\%/100\%) e IC (100\%/100\%). Os resultados foram submetidos à análise estatística com o teste exato de Fisher ou o teste Qui-quadrado de Pearson com o nível de significância de 5\% $(p<0,05)$. Com base na análise estatística dos resultados concluiu-se que não houve diferença estatisticamente significante entre os grupos no período de tempo avaliado.

UNITERMOS: Lesão cervical; Resinas compostas; Cimentos de ionômero de vidro.

\section{REFERENCES}

1- American dental association. Council on Scientific affairs. Acceptance program guidelines. Restorative Materials;1996. p.19.

2- Bayne SC, Heymann HO, Studervant JR, Wilder AD, Sluder, TR. Contributing co-variables in clinical trials. Am J Dent 1991; $4: 247-50$.

3- Browning WD, Brackett WW, Gilpatrick RO. Two-year clinical comparison of a microfilled and a hybrid resin-based composite in non-carious class V lesions. Oper Dent 2000; 25: 46-50.

4- Burrow MF, Tyas MJ. 1-year clinical evaluation of one-step in non-carious cervical lesions. Am J Dent 1999; 12:283-5.

5- Cardoso PEC, Braga RR, Carrilho MRO. Evaluation of microtensile, shear and tensile tests determining the bond strength of three adhesive systems. Dent Mater 1998; 14:394-8.

6- Duke ES, Lindemuth J. Variability of clinical dentin substrates. Am J Dent 1991; 4: 241-6.
7- Finger W, Fritz U. Laboratory evaluation of one component enamel/dentin bonding agents. Am J Dent 1996; 9:206-10.

8- Heymann HO, Bayne SC. Current concepts in dentin bond: Focusing on dentinal adhesion factors. J Am Dent Assoc 1993; 124: $27-36$.

9- Heymann HO, Studervant JR, Brunson WD, Wilder AD, Sluder, TR, Bayne SC. Twelve-month clinical study of dentinal adhesives in class V cervical lesions. J Am Dent Assoc 1988; 116: 179-83.

10- Heymann HO, Studervant JR, Bayne SC, Wilder AD, Sluder, TR, Brunson WD. Examing tooth flexure effects on cervical restorations: a two-year clinical study. J Am Dent Assoc 1991; 122: 41-7.

11- Hörsted-Bindslev P, Knudsen J, Baelum V. 3-year clinical evaluation of modified Gluma adhesive systems in cervical abrasion/erosion lesions. Am J Dent 1996; 9:.22-6.

12- Neo J, Chew CL, Yap A, Sidhu S. Clinical evaluation of toothcolored materials in cervical lesions. Am J Dent 1996; 9:15-8.

13- Powell LV, Johnson GH, Gordon GE. Factors associated with clinical success of cervical abrasion/erosion restorations. Oper Dent 1995; 20:7-13.

14- Sidhu SK, Watson TF. Resin-modified glass ionomer materials: a status report for the American Journal of Dentistry. Am J Dent 1995; 8: 59-67.

15- Yap AUJ, Neo JLC. No-carious cervical tooth loss. Part 2: management. Dent Update 1995; 22: 364-8.

16- Yoshiyama M, Carvalho RM, Sano H, Horner JH, Brewer PD, Pashley DH. Regional strengths of bonding agents to cervical sclerotic root dentin. J Dent Res 1996; 75:1404-13.

Recebido para publicação em: 10/02/2003

Aceito após reformulações em: 28/05/2003

To whom all correspondence should be addessed: Sérgio Lima Santiago

Rua Bárbara de Alencar, 1181 Apto. 502 - Aldeota

CEP: 60140-000

Fortaleza - CE - Brasil

Phone/Fax: 85 242-4121

E-mail: sergiosantiago@yahoo.com 